\title{
Preliminary assessment of the possibility of supporting the decomposition of biodegradable packaging
}

\author{
Lidia Niekraś ${ }^{1, *}$, and Ewa Moliszewska ${ }^{1}$ \\ ${ }^{1}$ Opole University, Department of Natural Sciences and Technology, ul. Kominka 6A, 45-032 Opole, \\ Poland
}

\begin{abstract}
This article presents a preliminary evaluation of the possibility of using grass biomass from a sports field as a compost ingredient which positively affects the degree of decomposition of the biodegradable wrappings. For 5 months the biodegradable bags were stored, both empty and filled with organic waste in the heap of grass clippings. After that period, fragments of the bags were observed under the microscope and then assessed the state of their decomposition. The results indicate that the biomass used favourably affected the process of bag degradation, however the speed of decomposition of the empty bags was quicker than the bags filled with the organic waste.
\end{abstract}

\section{Introduction}

Growing amount of the non-biodegradable waste materials obtained from the nonrenewable fossil sources, as well as their excessive storage in natural environment, induced materials industry to the search of the alternative solutions that shall be equally beneficial for both environment and consumer. As a result of the mentioned search, in 1995, first biomaterials - materials obtained from polymers which derive both from fossil materials and from renewable materials (biomass), appeared on the market. To the first group of the polymers belong, for instance, PBAT, PCL and PBS, whereas to the second group belong i.a. PLA (poly(lactic acid), polylactide), PHA (polyhydroxyalkanoates), TPS (thermoplastic starch). At the moment, it is worth pointing out that not every biomaterial will succumb to biodegradation in natural environment, as the biodegradation is not polymers' derivationdependent but its chemical structure-dependent [1]. The examples are, available on the market, renewable sources polymers with the Eko or Bio prefix, for instance, Bio-PE (polyethylene terephthalate), Bio-PP or Bio-PET [2]. The name, that sounds positively, relates only to the technique of their production during which polymers from petrochemical materials are not being used, what contributes, as well, to the reduce of greenhouse gas emissions, however, not to the decrease of the amount of stored waste. Waste that will be made of, in fact, will not decompose in natural environment but are going to be mixed into "plastic" stream of waste.

*Corresponding author: lniekras@wp.pl 
In 2015 global production of the plastic materials totalled 300 million tonnes of which biomaterials represented only 1\% [3]. European Bioplastics estimates that until 2018 their share in polymer materials will increase from 1.6 million tonnes in 2013 to 6.7 million tonnes per year. However, optimism of this forecast is being dampened down by the fact that the maximum growth of the production is predicted for non-biodegradable biomaterials such as Bio-Pe or Bio-Pet [2]. On the other hand, in case of biodegradable biomaterials, production of the PLA, i.e., polylactide, is going to be the fastest growing one [3].

Packing industry is the biggest customer of the polymer materials. This sector consumes nearly $40 \%$ of all polymer materials [4], therefore, it is going to be the main costumer of the biomaterials. What is more, considering the fact that the packets are of short duration parts of the products, it can be expected that in the short run, accumulation of waste from biodegradable packets will rise in natural environment. Even if we assumed that the packets would succumb to natural degradation, the fact that this process needs both an appropriate period of time and proper conditions, must be remembered.

Organic waste is an appropriate place of lodging of the worn biodegradable packets. During process of their liquidation, two basic biochemical treatment methods of waste are being used, i.e., composting or anaerobic digestion [1]. Composting, as the natural utilization, is the less expensive method of developing of the biodegradable waste. It consists in transformation of organic substance with presence of oxygen and microorganisms into $\mathrm{CO}_{2}$, water and biomass [5]. The appropriate conditions are necessary for the proper process of composting: efficient supply of oxygen, high level of humidity, $\mathrm{pH}$, and appropriately high temperature [5]. It is thought that the temperature is the main factor that decides about the species number and diversity of the composting microorganisms. Mesophilic, termophilic and temperature decreasing phases can be distinguished during the maturation of the compost [6]. Moreover, every phase is characterised by distinct microbiological composition. For instance, in termophilic phase, bacteria are dominant [7], while yeasts are not detected, whereas in temperature decreasing phase, fungi of the Aspergillus spp. and Mucor spp.,[6] are being observed, and the presence of actinobacteria is noticed in mature compost [8]. The above information shows that the composting must take place in controlled conditions what is possible only during industrial composting. In case of home composting, even the range of temperatures is significantly lower, what makes the process harder and much slower [9].

In purpose of minimising of organic waste storing, the method of home composting is increasingly popular. More and more frequent appearance of biodegradable biomaterials in the stream of waste should be expected. On the market, there are even biodegradable plastic bags, used for household waste bins, which were declared by the manufacturer [10]. According to the above information, if the conditions in compost bin are not appropriate enough, the amount of the plastic film with organic waste will be very large in a short time. Moreover, closing of waste in a bag, may, for example, cause a limit of access of oxygen to the composting components and dieback of aerobic organisms, which can be replaced by anaerobic organisms [11]. This, as the result, may cause a complete inhibition of the process.

Considering, household waste bins' beddings are important for the process of composting [12], so the research of the influence of grass cuttings biomass's potential on household waste films was realized. Grass cuttings were used as the factor stimulating decomposition of the biodegradable plastic bags used for filling in home compost bins. In the present article, a characteristic of grass cuttings' biomass from a pitch was made. In the last part, initial results of the observation of the range of researched plastic film's decomposition, conducted with use of light microscope, are presented. 


\subsection{A brief characteristics of the lawn grasses creating turf of a pitch}

The following three species of the turff grasses are predominant on the Polish stadiums: common meadow-grass Poa pratensis L., English ryegrass Lolium perenne L. [13] and two subspecies forms of red fescue [14]: Chewing's fescue (Festuca rubra ssp. commutata) and Creeping red fescue (Festuca rubra ssp. rubra) [15]. 50-70\% of the total mixture of grasses intended for pitches falls for common meadow-grass. Maximally $20 \%$ of English ryegrass and about $10 \%$ of Red fescue. The selection of such and no other grasses results from their high resistance to mechanical damages (trampling and frequent mowing) as well as high resistance to diseases, including the most frequent in our geographical area - stem rust caused by the fungus Puccinia graminis and leaf spot, caused by Drechslera sp. Fungi. Furthermore, these are short grasses with firm root system that are tillering strongly[16-20]

\subsection{Maintanance that improves the quality of biomass derived from the grass mown on a pitch}

The high quality of turf is provided by complex maintenance that can be distinguished to basic, supporting and regenerating maintenance [22]. Providing proper humidity of grass substratum guarantees good growth from planting to the moment of grasses tillering. Average daily need of turf for water is about 4 litres of water $/ \mathrm{m} 2$ and during spring and summer period it increases to about 7.5-15 litres of water $/ \mathrm{m}^{2}$. As the grasses use nutrients present in the shallow soil, the sterilisation of the layer high in nutrients appears very quickly. That is why the turf of the pitch should be fertilised regularly with nitrogen, phosphorus and potassium (in following proportion: 4:1:2) and regularly aerated what improves gas exchange and increases water absorption [23].

In view of the foregoing, one can expect that the care of how the pitch turf looks will cause that the quality of waste biomass created as a result of frequent mowing and verticulation (i. e. clearing the necrosing parts of grasses) is going to be better than, for example, the quality of biomass received as a result of mowing the city park lawn.

Biomass of the grass species that create turf, in contrast with fodder grasses, is not tall, therefore incineration seems as energy unprofitable. Moreover, in accordance with Turski, organic waste with high humidity and lack of structure, as for example, grasses, essentially qualify for methanogenesis [26]. However, in our country, the development of biogas plants is slow, so other solutions shall be found [27]. Undoubtedly, the less expensive method of organic waste treatment is composting, meanwhile in Polish conditions the dominant is still uncontrolled storage of organic waste. Due to the above, searching for solutions that will change the situation, is justified.

The aim of the experiment was the initial evaluation of the potential of mown grass's biomass from the turf of a pitch to help with decomposition of the biodegradable packets used for bedding of the home compost bin.

\section{Experimental materials}

Prisms of mown grass from the 8000 square meter pitch of Centre of Sport and Tourism in Dobrzyń (Kuyavian-Pomeranian Voivodeship) were used.

The composition of the mixture of grasses for the turf included: $70 \%$ of English ryegrass, $15 \%$ of common meadow-grass and $15 \%$ of red fescue. Before the planting, bedding of the turf was analysed in laboratory. In accordance with the analysis, professional firm that builds and renovates pitches, matched the proper plan of fertilising and a schedule of basic, supporting and regenerating maintenance. Frequency of mowing and the amount of sourced biomass was not constant and was dependent on growth rate of the grass. From 
March to the first half of April the grass was mowed once a week and every mowing was giving on average $1.8 \mathrm{~m} 3$. Then, from April to June and afterwards, from July to August, the frequency of mowing increased to two times a week. However, in the first case, there was $3.9 \mathrm{~m} 3$ of biomass per mowing, while in the second case $2.1 \mathrm{~m}^{3}$. In September and in October the turf was mowed once a week and $1.3 \mathrm{~m} 3$ of biomass was obtained.

Biodegradable bags (according to manufacturer's declaration) (Fig. 1a) were stretched on a wooden frame and in such a form, they were placed in the prism of grass from the pitch (Fig. 1b) in July. In order to compare the results of observation, the prism of grass from the city park lawn, was prepared (the species composition was the same). The city park lawn was not maintained as well as the pitch turf. What is more, it was exposed to excrements of animal origin (Fig. 1c). It was also decided to examine the biodegradable bags according to the producer instruction, and for this purpose they were filled with organic household waste (selected eggshells, peelings from vegetables and fruits). This part of the experiment should show if the substances present in the household waste will really help to increase the process of their decomposition (Fig. 1d). The experiment took 5 months, during this time the prisms were regularly dampened. After this period of time, the range of the examined bags' decomposition was evaluated and the microscopic observation was made.

\section{Results}

In the experiment the general condition of the composted bags was assessed as well as their structure, colour, flexibility, tearing and cracking and the degree of transparency (Tab. 1). The results clearly showed that the producer' declaration concerning the possibility to biodegradation in the six week period of time is not possible, although some symptoms of biodegradation were noticed. The best degree of biodegradation was observed for the clean bags composted in the prism of the pitch grass and for the bags filled with household waste and buried in the prism of the pitch grass (Tab. 1).

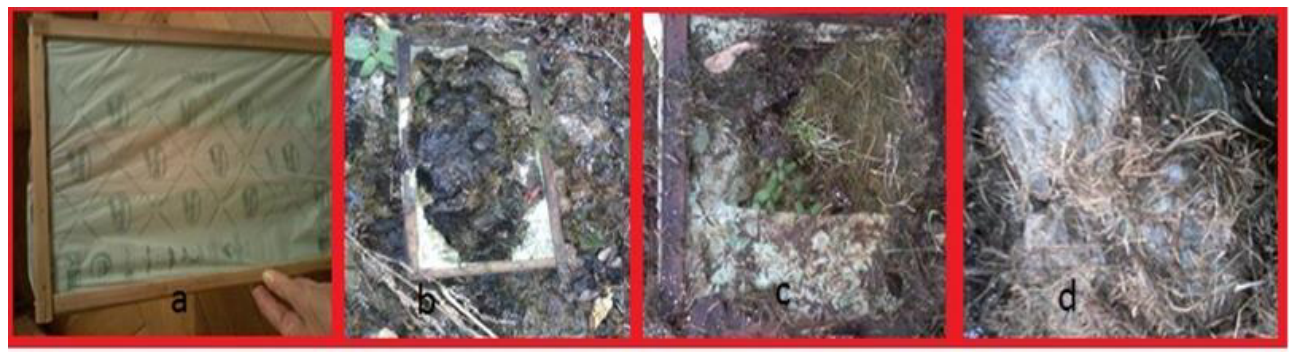

Fig. 1. A biodegradable film, a) a new, not used film - control, b) composted with football pitch grass, c) composted with grass, d) composted with household. 
Table 1. Influence of the way of composting on the degree of decomposition of biodegradable bags.

\begin{tabular}{|c|c|c|c|c|}
\hline $\begin{array}{l}\text { Sample } \\
\text { Feature }\end{array}$ & $\begin{array}{l}\text { 1- Control (a } \\
\text { new bag) }\end{array}$ & $\begin{array}{c}2 \text { - A bag } \\
\text { composted } \\
\text { in a prism of } \\
\text { municipal } \\
\text { grass }\end{array}$ & $\begin{array}{l}3 \text { - A bag } \\
\text { composted in } \\
\text { a prism of } \\
\text { pitch grass }\end{array}$ & $\begin{array}{c}4 \text { - A bag with } \\
\text { household waste } \\
\text { composted in a } \\
\text { prism of cut pitch } \\
\text { grass }\end{array}$ \\
\hline $\begin{array}{l}\text { General } \\
\text { condition }\end{array}$ & $\begin{array}{l}\text { In touch- } \\
\text { silky, with no } \\
\text { visible } \\
\text { delamination } \\
\text { Fig la }\end{array}$ & $\begin{array}{l}\text { Unpolished } \\
\text { with no } \\
\text { delamination, } \\
\text { in the } \\
\text { experimental } \\
\text { frame partly } \\
\text { not changed } \\
\text { Fig } 1 \mathrm{~b}\end{array}$ & $\begin{array}{l}\text { Unpolished with } \\
\text { numerous } \\
\text { points of } \\
\text { delamination, in } \\
\text { the experimental } \\
\text { frame partly } \\
\text { lack of the film } \\
\text { Fig } 1 \mathrm{c}\end{array}$ & $\begin{array}{c}\text { Unpolished but very } \\
\text { comparable to the } \\
\text { control one (new one) } \\
\text { Fig ld }\end{array}$ \\
\hline Structure & Guttiferous & As a thin paper & Parchment & As a thin parchment \\
\hline Colour & $\begin{array}{l}\text { Light-green } \\
\text { colour } \\
\text { Fig } 3 a \\
\end{array}$ & $\begin{array}{l}\text { Light-green } \\
\text { colour Fig } 3 b\end{array}$ & $\begin{array}{l}\text { Khaki colour } \\
\text { Fig } 3 c\end{array}$ & $\begin{array}{c}\text { Khaki colour } \\
\text { Fig } 3 d\end{array}$ \\
\hline Flexibility & $\begin{array}{l}\text { Has inherent } \\
\text { flexibility }\end{array}$ & $\begin{array}{c}\text { Lack of } \\
\text { flexibility, } \\
\text { fragile }\end{array}$ & $\begin{array}{c}\text { Lack of } \\
\text { flexibility, } \\
\text { fragile }\end{array}$ & $\begin{array}{l}\text { Lack of flexibility, } \\
\text { fragile }\end{array}$ \\
\hline $\begin{array}{c}\text { Susceptibili } \\
\text { ty to tearing } \\
\text { and } \\
\text { cracking }\end{array}$ & $\begin{array}{c}\text { Stretchable, } \\
\text { bursting with } \\
\text { adequate } \\
\text { strength along } \\
\text { the fibers } \\
\end{array}$ & $\begin{array}{l}\text { Susceptible to } \\
\text { cracking and } \\
\text { tearing with } \\
\text { any effort }\end{array}$ & $\begin{array}{c}\text { Very susceptible } \\
\text { to cracking and } \\
\text { tearing with any } \\
\text { effort }\end{array}$ & $\begin{array}{l}\text { Very susceptible to } \\
\text { cracking and tearing } \\
\text { with any effort }\end{array}$ \\
\hline Clarity & $\begin{array}{c}\text { A low } \\
\text { transparency }\end{array}$ & $\begin{array}{c}\text { A low } \\
\text { transparency }\end{array}$ & $\begin{array}{c}\text { A great } \\
\text { transparency }\end{array}$ & $\begin{array}{c}\text { A very high degree of } \\
\text { transparency }\end{array}$ \\
\hline
\end{tabular}

The results of the observation of the 3 samples correlated in table 1, show that in comparison with control sample, the only visible feature in all tested samples is lack of the bag's flexibility. The other features are not visible in all tested samples. The look of a bag composted in a municipal grass is the most similar to the original bag. Its light-green colour and level of clarity (Fig. 3b) is exactly the same as in control sample (Fig. 3a). The differences in susceptibility to tearing and cracking are the smallest there as well. This may suggest that the unmaintained municipal grass additionally exposed to, for example, excrements of animal origin, does not contain substances supporting decomposition (e.g. enzymes) of the biodegradable bag declared by the manufacturer. On the other hand, bags stored in a prism of pitch grass, both the clean ones and filled with organic waste, show the significant differences in comparison with control sample. Their khaki colour (Fig. 3c and $3 \mathrm{~d}$ ), susceptibility to tearing and cracking with any effort, finally the structure of a bag changed from guttiferous to parchment-like or even to structure of a thin tissue paper, may show the presence of factors beneficially influencing the level of biodegradation of examined packets in biomass of cut pitch grass. In order to countercheck this assumption, the further research of biomass of cut pitch grass are necessary. Nevertheless, one may assume that the way of maintenance may have a beneficial influence on the biodegradable potential of biomass obtained in that way (e.g. the amount and quality of enzymes). This 
can be showed by the fact that both municipal lawn and pitch turf had the same species composition in the research.

However, in the conducted microscopic observations (optical microscope magnifying), such a vast changes in the look of experimental packets (Fig. 2b, 2c, 2d) like in case of macroscopic evaluation (Fig. 1a, 1b, 1c, 1d) were not possible to be observed. It was hard to see even the smallest cracks or perforations in bags that after 5 months confirm progressive process of their biodegradation.

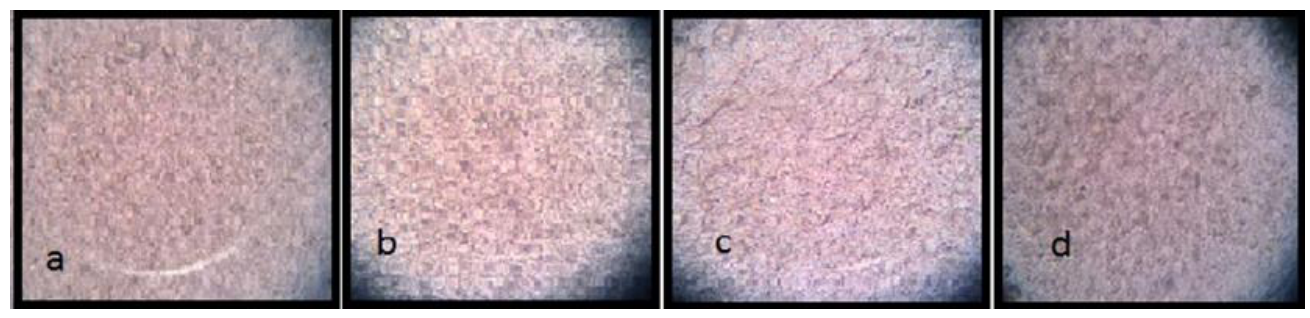

Fig. 2 Microphotograph of biodegradable film, a) a new, not used film - control, b) composted with grass, c) composted with football pitch grass, d) composted with household.

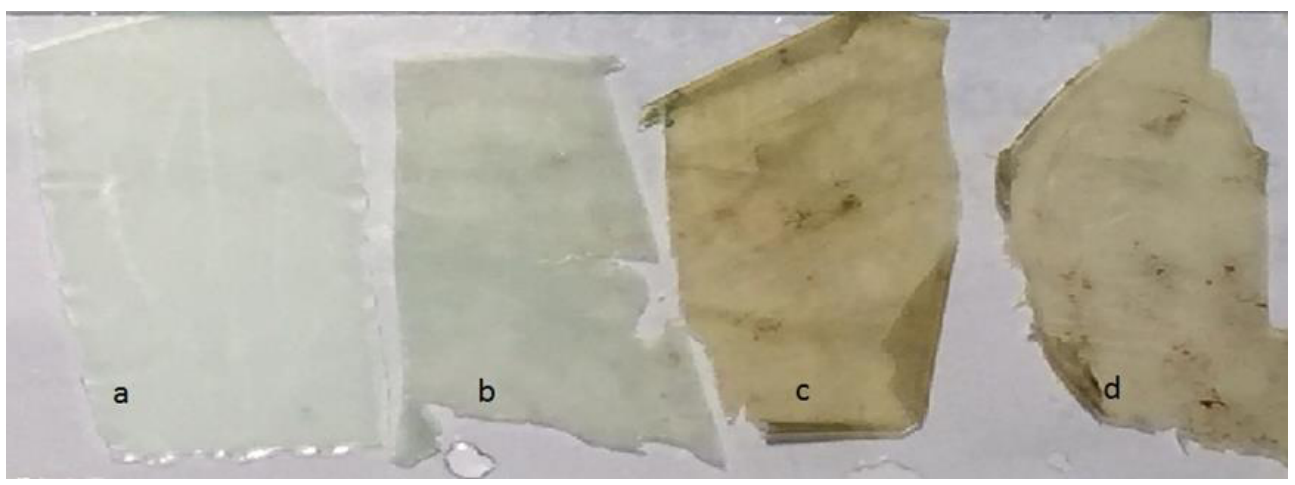

Fig. 3 Macrophotograph of biodegradable film, a) a new, not used film - control, b) composted with grass, c) composted with football pitch grass, d) composted with household.

\section{Conclusions}

1. Different ways of composting biodegradable bags for household waste proceed in with varying results of the degree and the rate of decomposition.

2. None of the methods of composting of biodegradable bags for household waste was compatible with the manufacturer's declaration.

3. Further research is needed to investigate the conditions of biodegradation of biodegradable bags, including studies using household waste and grass cut from pitch.

\section{References}

1. http://www.plastice.org/fileadmin/files/Polish_WEB.pdf

2. R. Malinowski, Inżynieria i Ochrona Środowiska, 18 (2), 215-231 (2015)

3. H. von Pegnelli, Biotworzywa, 1, 7-12 (2015)

4. http://www.plasticseurope.org/documents/document/20150127125822-tworzywafakty_2014_final.pdf

5. A. Jędrczak, Biologiczne przetwarzanie odpadów (PWN, Warszawa, 2007) 
6. J. Ryckeboer, J. Mergaert, K. Vaes, S. Klammer, D. De Clercq, J. Coosemans, H. Insam, J. Swings, Ann. Microbiol., 53, 349-410 (2003)

7. P. Manczarski, Kompostowanie odpadów komunalnych. Referat na Forum Technologii Ochrony Środowiska POLEKO 2007 (2007)

8. C. G. Golueke, Bio Cycle, 33, 55-57 (1992)

9. http://www.cobro.org.pl/nip/images/stories/PORADNIK/bioplastics pl_internet.

10. L. Nikeraś, Interdyscyplinarne zagadnienia w inżynierii i ochronie środowiska, 7, 129136 (2016)

11. K. Pilarski, A. Pilarski, Technika Ogrodnicza, Rolnicza, Leśna, 1, 16-17 (2009)

12. K. Ishii, S. Takii, J. Appl. Microbiol., 95, 109-119 (2003)

13. P. Dąbrowski, B. Pawluśkiewicz, Przegląd Naukowy Inżynieria i Kształtowanie Środowiska, 51, 27-35 (2011)

14. K. Wolski, M. Talar-Krasa, A. Dradrach, M. Szymura, M. Bierniacik, S. Świerszcz, Łąkarstwo w Polsce, 18, 241-254 (2015)

15. B. Rutkowski, A. Hempel A., Trawniki (PWRiL, Warszawa, 1986)

16. S. Prończuk, Biul. IHAR, 186, 127-132 (1993)

17. https://biologiaroslin.wordpress.com/2012/06/16/trawy-na-murawy/

18. http://www.ihar.edu.pl/gazony.php

19. D. Martyniak, Biul. IHAR, 228, 335-344 (2003)

20. M. Prończuk, Choroby traw - występowanie $i$ szkodliwość $w$ uprawie na nasiona $i$ użytkowaniu trawnikowym (Monografie i Rozprawy Naukowe, IHAR, Radzików, 2000)

21. http://www.trawnik.com/?aktyw_kat=4\#.WJzFU3-XeM8

22. http://www.trawasportowa.pl/pdf/pielegnacja.pdf

23. www.bip.lubniewice.pl/bip_download.php?id=852

24. http://www.mrgreengrass.pl/uslugi/zabiegi_pielegnacji_boisk.html

25. http://www.victus.pl/porady-eksperckie/pielegnacja_trawnika/

26. S. Baran, R. Turski, Wybrane zagadnienia z utylizacji i unieszkodliwiania odpadów (Wydawnictwo AR, Lublin, 1999)

27. http://magazynbiomasa.pl/szanse-dla-biogazu-po-1-stycznia-2016-r/ 